\title{
Engaging Disaster Prone Communities; Pre-impact Media Blitzing
}

\author{
Douglas Goudie \\ School of Earth and Environmental Sciences, James Cook University, North Queensland 4811 \\ *Corresponding Author: douglas.goudie@jcu.edu.au
}

Copyright (c) 2013 Horizon Research Publishing All rights reserved.

\begin{abstract}
Recent research shows fire-prone residents and regional fire managers in SE Australia converge in wanting more local, detailed information available to the threatened, and that this does not happen in a vacuum. Communities in hazard zones need to be and feel engaged with the realities of their local threats, empowered and supported to act, maximising their own and their community's safety. This paper shows that engaged, informed communities can be fostered through emerging use of the internet and Common Alert Protocols. More geographically targetted pre-impact media exposure about the likely extent and impacts of the threat is recommended.
\end{abstract}

Keywords Natural Disasters, Disaster Risk Reduction, Effective Risk Communication, Media, Self-Help, Evacuation, Bush Fires, Community Safety, Crisis Communication

\section{Introduction}

Risk communication after 7/2/2009

The rules for engagement for disaster risk management were largely rewritten in Australia after the 1939 and 1983 SE Australian fires. They underwent a quantum change after Cyclone Tracy and the Brisbane floods of 1974.Those rules have evolved further following the firestorms of Black Saturday, 7 February 2009 in SE Australia, where 173 people died. People were overwhelmed by the speed and ferocity of fires on the hottest day in Victoria's record. There were many days' prior warnings of extra fire threat across the media.

This paper considers how to maximise community preparedness, based on meetings and surveys with regional fire managers and fire-prone residents early in both 2007 and 2008. Ninety-two bushfire-prone households in five South-East Australian regions were interviewed in 2007, asking how people received their bushfire information and warnings, and asked for ways to improve community and householder preparedness and the effectiveness of emergency warnings. Considerable portions of exurban SE
Australia's built environment are seen as among the most fire-prone on earth.

Results from 2007 and a feedback iteration in early 2008 show that effective risk communication is about community self-help and the rapid sharing of local information with the fire-threatened. Some communities, particularly beyond the periurban areas, are highly threat aware, self-protecting and inter-supportive. Some areas had high local innovation in sharing preparedness and emergency warnings. This article uses bushfire awareness, preparedness, response and early recovery as a lead example of trends in crisis communication, engaging community members to help people get safe and stay safe (Boura 1998, Ingirige and Amaratunga 2012), the globally shared disaster management goal (UNISDR 2012).

This paper draws on original research and current literature to advance the use of the internet to minimise the losses associated with disaster impacts in this time of global warming and increasing global populations moving into greater hazard zones, such as in Bangladesh (Ingirige and Amaratunga 2012). Research and theory, including adult learning theory, underline that adults, to act, most prefer a practical, problem solving approach, familiar and relevant to their own lives; ways of sharing and drawing oncommunity-members prior experience; having a two-way, active role in information exchanges with varied and trusted sources(Steelman and McCaffrey 2012).Steelman and McCaffery also note there is little reported work on fire risk communication. This paper and associated references (i.e. Goudie 2007, Sorensen 2013) help address that. It is firmly embedded and extends from other, mainly Australian disaster risk communicators, such as Handmer (1992, 2000, 2001; Rohrmann $2000 \mathrm{a}+\mathrm{b}$, and Paton 2003, Paton et al 2005).

There is a strong convergence of finding from the 2007 and 2008 research reported in this paper and recent findings of Steelman and McCaffrey (2012), and of Yang and Kahlor (2013). All converge on the physical realities, the psychology of engagement - or active information avoidance, and how to achieve maximum safety. Of the 92 fire-prone householders interviewed for this research in 2007, almost all asked for greater real-time fine local detail. This has helped shape the Australian Bureau of Meteorology's fire 
weather and other warnings, both information detail and timeliness of release. The role of the media has also stepped up, aligned to Australian Federal Government policy (COAG 2004), in many ways led by $\mathrm{ABC}$ radio and more recently, $\mathrm{ABC}$ news 24 digital television. A deep study by the Australian Government in 2013 found one of the greatest requirements of peoples in Northern Australia affected by cyclones was real-time local information (Sorensen 2013), convergent with this reported research.

This project was funded by and conducted jointly with and for the Australian Bureau of Meteorology and the Australian Bushfire Cooperative Research Centre (Goudie 2007, 2009a).

This paper aims to help improve the background preparation and triggers to action ahead of and through a natural disaster impact, focused on self-help among the bush-fire prone. The reported research was conducted with fire managers and residents in high risk built environments in south east Australia, and includes results of household surveys. After defining the aim and outlining the methodology, a two fire-season survey of feedback from the fire-prone about what sorts of risk communication they want, and refinement of that end-user driven research, results are given, then compared and integrated with government policy and current risk communication psychology and literature. Recommendations are given, particularly encouraging media sources to increase their pre-impact coverage into threatened areas in proportion to the likely severity of the impact.

\section{Aim}

This research aimed to help improve effective risk and crisis communication by working collaboratively with regional fire authorities in five fire hazard zones in SE Australia's built environments, interviewing at-risk households about how they felt effective fire-risk communications can improve.

\section{Method}

Bushfire household risk communications survey - early 2007

Aiming to understand how at-risk residents received their emergency warnings and early recovery information and how to improve that information and delivery, this research worked closely with state and Territory fire authorities. It was conducted over two fire seasons, and so results are given that way. No two fire seasons are the same.

In early 2007, fire zone residents in Victoria, Canberra and New South Wales were surveyed in face-to-face household interviews averaging about 30 minutes. Local fire managers directed researchers into 11 high risk "fire zones" (fire-prone areas).Early 2007 was an acute fire season so interest was high, producing detailed feedback.

Twenty-three surveys were completed in the Bega Valley bush, SE NSW, 12 on Canberra bush edges (1/2 fire-affected in 2003), 33 in Yarra Ranges fire zones, NE of Melbourne; 14 on the Mornington Peninsula among tea-tree forests south of Melbourne and 10 on a North Sydney bush edge. The survey began: "We are looking for your views on bushfire warnings and preparedness."

There was a fixed survey instrument, which included question Q2.4: "What are your main ways of learning about bushfire threats? Look at the Guide Sheet, and tell me which fire information source you rely on most which do you use next most often. Are there other information sources you use[prompt]:Radio, TV, Internet/web, Local newspapers, Pamphlets, Banners or road signs, Friends, Neighbours, Family, Meetings, Other. Responses were listed as a number, 1 being the first designated information source.

There were further prompts relating to internet use. Following some details on what sites were used, recipients interested in the internet were asked (Q 3.10):"If we had a new, national web site for information for people in Bushfire zones, and we asked you to design the front page for easy use, how should the front page look. What else would the site have? How would it look and work?"

Arranged by fire managers, as well as the 92 Household surveys conducted in the 5 fire zones, numerous community meetings were held in early 2008, to give feedback from and refine input to the research findings of 2007. Three public meetings were held on the Mornington Peninsula early in 2008, and four in parts of Canberra deeply affected by their 2003 fires. Feedback from the surveyswas gained early in 2008 from Fire managers (Mornington Peninsula), managers and brigade members (Bega Valley); Managers and 22 Community Fireguard (CFA 2008) members from across the Yarra Ranges. Early 2008 was a relatively mild fire season.

\section{Results}

In 2007, those who had experienced a bushfire or had close contact with a fire survivor take the threat most seriously. People connected to local brigades, or in community fireguard or fire units tended to be more fire-prepared than others. Residents of the deep bush are much more prepared and interlinked than many on the urban fringe. $\mathrm{ABC}$ radio was appreciated by many. Radio is the dominant information source (Figure 1), followed by friends and family. ("Which fire information source do you rely on most?") 


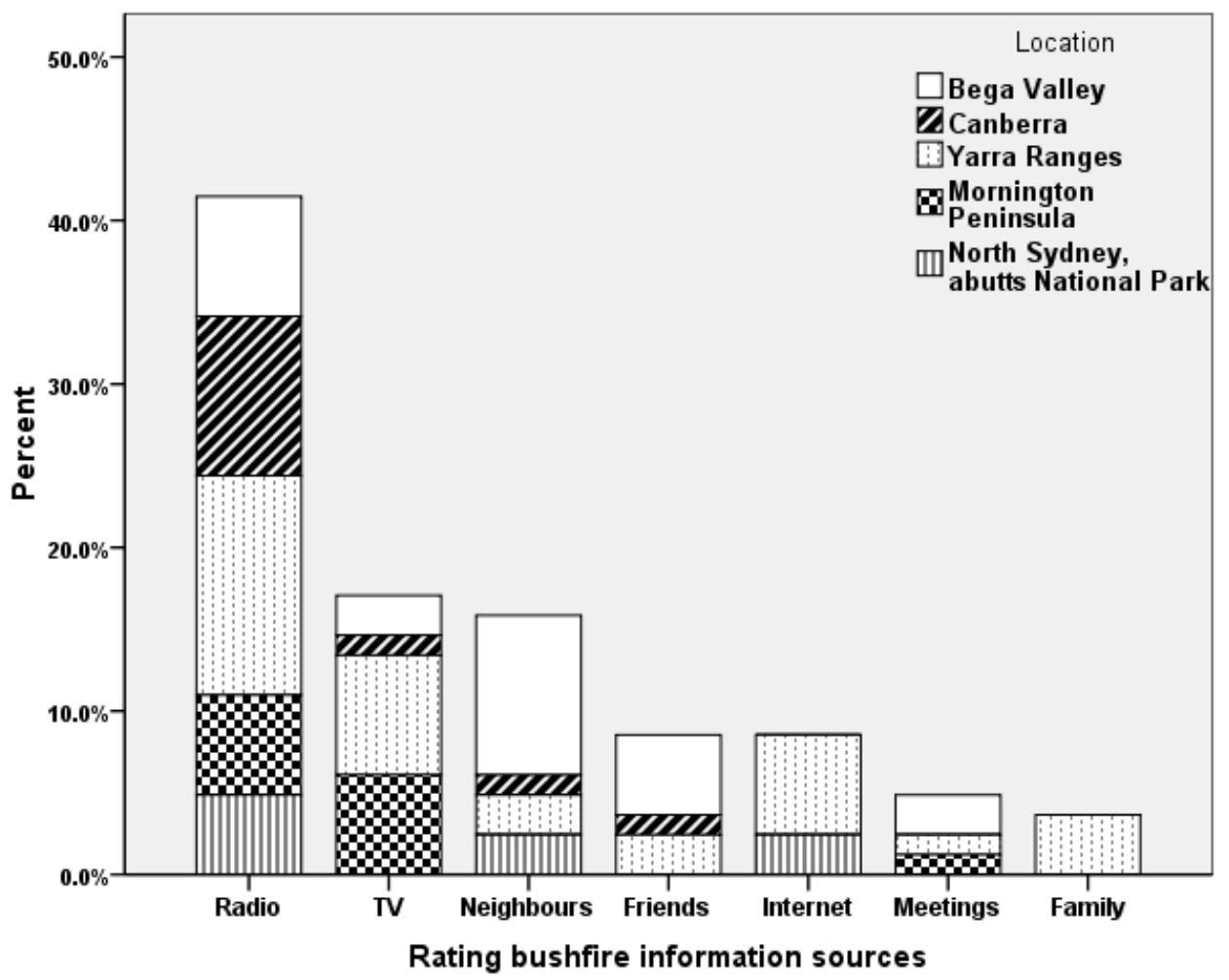

Local newspapers, Authorities, Banners, road signs and pamphlets were nominated by less than $5 \%$ of respondents. Figure 1. Most relied-on fire information sources

The internet is widely used, but 262 suggestions were given to improve it (Figure 2), especially wanting greater ease of access to fine local detail and 'now-casting', pivotal to 'stay or go' decisions.

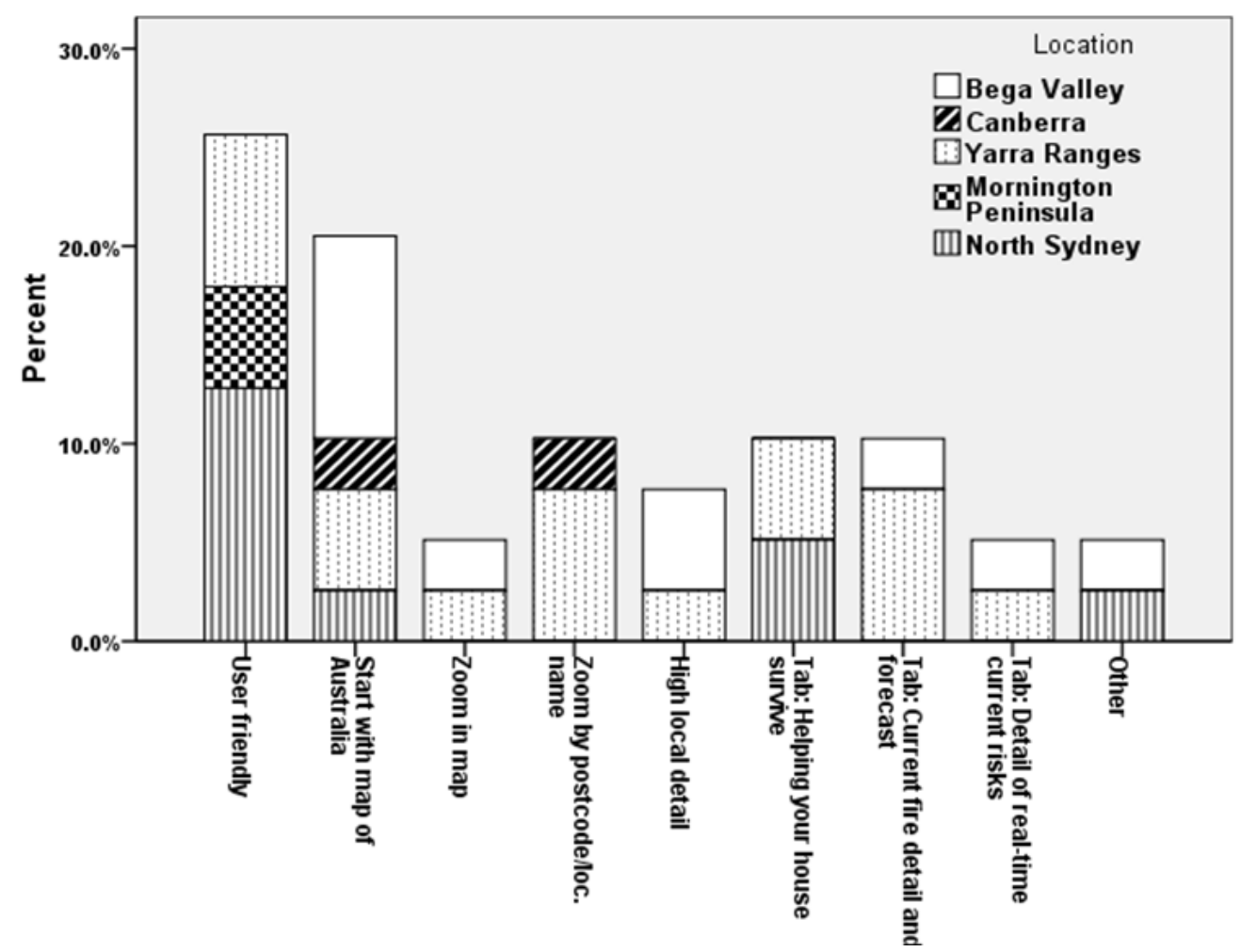

Figure 2. What fire zone internet users want from a fire web site 


\subsection{Suggested Ways to Improve the Internet}

'Other' includes: Tab: as fire approaches; Tab: Helping your house survive; Tab: Landscaping and building advice; Tab: Current deployment of all resources; Tab: Fire history of my area; Tab: All related local phone \#; Tab: Detail of real-time current risks; Tab: real-time fire map and predictions; Tab: Wind direction and speed; Consider all disasters; Tab: Psychology and coping sites; Tab: managing livestock/pets; Tab: pictures of clothes and gear needed; Tab: detailed evacuation issues; Tab: People new to the area; Community email newsletter; Links to related sites; Push for fire plan.

Descriptive analysis was conducted on the 2007 data set, but as the survey was more qualitative than quantitative, no great statistical insights were gleaned. It was clear (Table 1) that there was only a weak but significant (to .09) correlation (Peasons 2-tailed .18) between perceived housing vulnerable and how seriously residents took bushfire threat. Close scrutiny of various analysis sets found little of advanced statistical interest, because the data gathered was mainly descriptive. It is the strong interest in better information from multiple sources which is the main research result.

\subsection{Results: Sharing Local Innovation Nationally}

In the Bega Valley, the strong sense of community, an acute shared sense of vulnerability and interdependence produced innovation such as road-side blackboards for fire updates and for community meetings. The city-fringe equivalent could be electronic roadside signs. Bulk emails proved effective in one area; community-initiated installation of a UHF tower works in another. Monitoring official VHF information and practicing bushfire awareness and drills in one retirement village were developed in the Yarra Ranges. Campers are actively targeting on the holiday camping grounds of the Mornington Peninsula, while specific text messages are ready for group sending in one area. Phone trees work in the deep bush, but people need answering machines to reduce stress on callers. Phone trees were more up-to-date in remote areas than in the urban fringes. A supported 'bush' idea was for 'over-managed' local social burn-offs near vulnerable houses.

Twenty-two Community Fireguard Group (CFG) Yarra Ranges residents want big, simple, well placed and interesting road signs. A well-attended and supported community safety day was held in 2008 in the fire-impacted area of Canberra, where the 2007 results were shared and feedback gained to refine Figures 3 and 4.

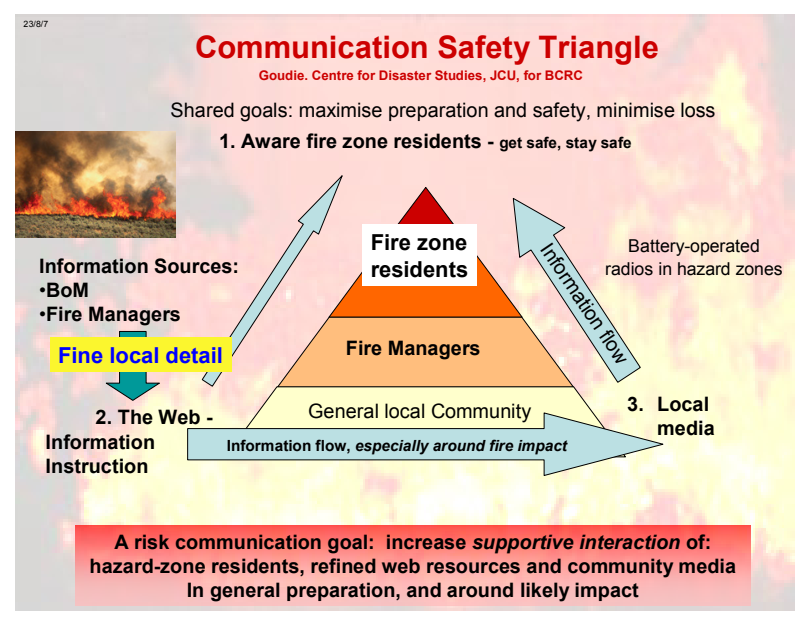

Figure 3. The Communication Safety Triangle (CST)

Table 1. Correlation of perceived house vulnerability to how seriously a bushfire threat was taken

\begin{tabular}{|c|c|c|c|}
\hline & & $\begin{array}{c}\text { Housing } \\
\text { vulnerability }\end{array}$ & How seriously you take a bushfire threat \\
\hline \multirow{3}{*}{$\begin{array}{c}\text { Housing } \\
\text { vulnerability }\end{array}$} & Pearson Correlation & 1 & .178 \\
\hline & Sig. (2-tailed) & & .090 \\
\hline & $\mathrm{N}$ & 92 & 92 \\
\hline \multirow{3}{*}{$\begin{array}{c}\text { How seriously } \\
\text { you take a } \\
\text { bushfire threat }\end{array}$} & Pearson Correlation & .178 & 1 \\
\hline & Sig. (2-tailed) & .090 & \\
\hline & $\mathrm{N}$ & 92 & 92 \\
\hline
\end{tabular}

Goal: Maximise safety and recovery, and minimise loss in hazard zones.

For Emergency Managers

1. Encourage those in hazard zones to accept that the risks are real.

2. Help create an aware, informed community, predisposed to safety-oriented action, as a precaution; as a practice.

3. Encourage information-sharing and support among friends, neighbours, family.

4. Provide 'what to do' (action) information, via reliable sources, including web and local media delivered for background and preparation.

5. Encourage people to think right through to impact and recovery.

6. When a threat is closing in, waming messages will clearly convey: this is real, this is coming at me. Ineed to make safe where I am, or move early to somew here much safer. I will not travel during the impact period.

7. Provide timely, effective threat wamings and fine location and forecast weather detail, and recommended local responses.

Figure 4. Seven Steps to Community Safety 
The Mornington Peninsula meetings included 8 CFA Brigade Administration Support Officers (mainly for community liaison) and with the Municipal Fire Prevention Officer. They highlighted fuel load, the need to engage community, and using all available networks and media to rapidly get 'now' information from the fire-field to those at risk. Community radio staffs were open to reading timely local warnings from the web (Figure 3), and want to be included in local emergency planning. Earlier versions of Figures 3, 4 and 7 were presented to and supported by these groups. Their incorporated feedback informs the final versions of those figures. The 2008 input included written submissions by 39 fire zone residents, commissioned to fill in survey forms at fire-authority organized community meetings. Those meetings and residents who filled in the 2008 survey forms largely echoing the need for fine local detail in time and space, the need to have backup sources of emergency warnings, such as local 'phone trees'. There were 81 total nominated first, second and third levels of final information sources, shown in the descriptive data of Table 2.

Table 2. Main bushfire threat information sources

\begin{tabular}{|c|c|c|c|c|}
\hline $\begin{array}{c}\text { Main final } \\
\text { information } \\
\text { source }\end{array}$ & $\begin{array}{c}\text { Frequency } \\
1 \text { st } \\
\text { nominated }\end{array}$ & 2nd & 3rd & Total \\
\hline Radio & 11 & 11 & 5 & 27 \\
\hline Internet & 7 & 4 & 3 & 14 \\
\hline Scanners/UHF & 7 & 2 & 1 & 10 \\
\hline Phone tree & 4 & 4 & 2 & 10 \\
\hline Authorities & 3 & 4 & - & 7 \\
\hline Neighbours & 2 & 2 & 1 & 5 \\
\hline Sirens & 4 & 1 & - & 5 \\
\hline Fireguard group & 1 & 2 & - & 3 \\
\hline Total & 39 & 30 & 12 & 81 \\
\hline
\end{tabular}

Table two shows that there remained a high reliance on radio for emergency warnings, along with the internet. Radio scanners used by emergency managers and 'listened to' by some residents in poor radio or phone signal areas were relied on equally with phone trees. Information and warnings from 'Authorities' was important, but note 'neighbours', were the normal source of phone tree information, making neighbours (an 'informal' source) very important.

Written input includes suggestions for improvement such as:"A CFA radio station providing updates and hints during the fire period. Early warning is vital for me as I live a long way from work." "Total fire ban signs, heat and winds make it obvious." There is general apathy in my street re fire talk. I would suggest insurance companies include words of enticement to clients when sending out renewals." "Young people networking (texting) could be very useful - need to build networks of older/vulnerable and youth." "Formation of community fireguard groups. Street corner talks by local fire captains. Use CFA facilitators for group talks prior to fire season."

\section{Discussion}

An all-hazards approach is taken because many steps in maximising safety are basically the same (Handmer 2001, Goudie and King 1999, Goudie 2008a, 2013,Steelman and McCaffrey2012, UNISDR 2012): Crisis communication is the communication peak, through impact to early recovery (Figure 4). Core use of the internet for two-way, fine "now' information exchange and SMS-based messaging to those at risk was politically freed-up following the tragedy of February 2009.

\subsection{Modelling Making Better Community Safety}

The following models, refined in the regional meetings, are Communications Safety Triangle, 7 Steps to Community Safety, and the Preparedness Sequence (Figures 3, 4 and 7).

Current social theory (Kim and Ball-Rokeach 2006) and risk communication research (Rohrmann 2000a) champion informing and motivating people as inter-supportive community members (CFA 2003, Strahran 2008, Ingirige and Amaratunga 2012)to maximise their safety and recovery. The research reinforces that enhanced self-help community initiatives will help maximise safety(Paton et al 2005, Figure 4).All parties can be linked in one coherent approach to effective risk communication (Goudie 2004, King et al 2006and Sorensen 2013).

Established, interactive communities in high risk bushfire areas provide examples of engaged communities prepared to maximise safety, minimise impacts, speed recovery and minimise emergency demands on Authorities. Research indicates the inability of most people to be prepared for the most extreme event. Early and radical self-evacuation or highly accessible and fire-proofed shelter seem the only truly safe options for most in fire-vulnerable areas during predicted "firestorm weather".

The media is central in getting information from Authorities to those at risk (Rohrmann 2000b, Wakefield and Elliot 2003, Cohen et al 2006,Ingirige and Amaratunga 2012). The internet, and local media, particularly local ABC and volunteer-based community radio provide a vital role in crisis communication in Australia (Goudie 2009b). Effective now-casting from the Bureau of Meteorology and independent weather stations to people at risk can become a focus of crisis communication in threats like fast-moving fires.

An array of Common Alerting Protocols (Botterell et al 2008) will use the internet as the main information conduit to speed emergency managers' reality updates and decisions, more rapidly passing localised 'now' information to those at risk. Residents will ultimately access their authoritative web-to-air local information and advices via portable battery 
radio, emails or SMS messages, and share local 'action' information.

\subsection{The Communication Safety Triangle}

The CST "(Figure 3)" streamlines web-delivered information to householders via local media. Residents want local preparation information, real-time threat detail and recovery information (Goudie 2013, Sorensen 2013). The conditions for $7 / 2 / 9$ were well understood and forecast by the Bureau in the days leading up to 'Black Saturday' but there was insufficient media and Agency presence to properly convey the enormity of the risk. The Victorian Premier and others tried. For a predicted 'Category 5' or 'Firestorm weather/Catastrophic fire weather' day, warnings for the need to act radically were ineffective for many at risk. The core recommendation in this paper is: Leading into a predicted impact, the media should devote $10 \%$ of likely post-impact coverage in a geographically targeted and timely way to predicted impact zones, using language like fire weather and 'firestorm weather'. This regional bombardment by the media prior to weather-induced impacts will help neighbours talk and motivate each other to action, as a precaution, as a practice. A full theoretical framework for asserting the under-utilised importance of pre-impact targetted media blitzing draws on a synthesis of Bayesian Logic and Eigenvalues from the research results (Goudie 2013).

In an emergency, the CST embraces "WEB-TO-TV and WEB-TO-AIR" This means that authoritative information providers (including ground staff) deliver current, fine local detail to the web, so local newspapers and TV can provide images to convey threats and responses (Quarantelli 2002), while radio broadcasters are providing information off the web directly to their audiences via battery-operated radios. Fine-detailed local radio information to those at risk can use intimate local knowledge (Wakefield and Elliot 2003) and will achieve social good (COAG 2004) as authorities reach out to community organisations. This partnering may need to be facilitated. Each year the Bureau of Meteorology sends a letter to all media outlets 'reaffirming the partnership'.

\subsection{Steps to Community Safety (7SCS)}

The hardest steps in community self-help are having people accept that a threat is real, and that early self-help is necessary. The need to feel personal relevance, to internalise the reality to act, is central (Step 1, Figure 4).Cyclone Larry: cyclone forecast maps were used and appreciated (King et al 2006).

People at risk need to know, to 'internalise' that they are at risk before they are likely to act. People want to believe they will not be beset by calamity (King and Goudie 1998, 2006).

The remaining 6 steps are all to do with accepting the need to act.7SCS rejects 'she'll be right'; rejects 'they' will save me and my house'.
"Story telling" is emerging as a powerful tool to help make the threat 'real and local' to people (Wall 2006), because sharing stories of like prior events is important in two-way community engagement (Steelman and McCaffrey 2012).The 7SCS nests perfectly within the current UN approach to Disaster Risk Reduction (UNISDR 2012).

Like cyclone-prone residents (King et al 2006, Sorensen 2013), this bushfire research found complex partnerships and cooperative interactions maximised safety. People in fire zones tend to be either slightly aware of bushfire risks, or profoundly and acutely aware. The latter had often been in or near a bushfire. Figure 5 shows the roof gutters of a person living in an extreme bushfire situation - narrow winding gravel road, steep slope in among towering eucalyptus trees. They expressed little concern for their vulnerability. This 'enclave' in the Yarra Ranges, Victoria, shared a collective disregard for their vulnerability. Yang and Kahlor (2013) provide ample evidence that there are some people who actively avoid facing the realities of their vulnerability, because the information makes them feel uncomfortable. Such people represent, along with those with little or no English language, the greatest challenge to disaster risk management and communicators. They are the 'laggards' on the bell curve of normative values (O'Neil 2004) around internalising and acting on the threats associated with being in a hazard zone (Figure 4).

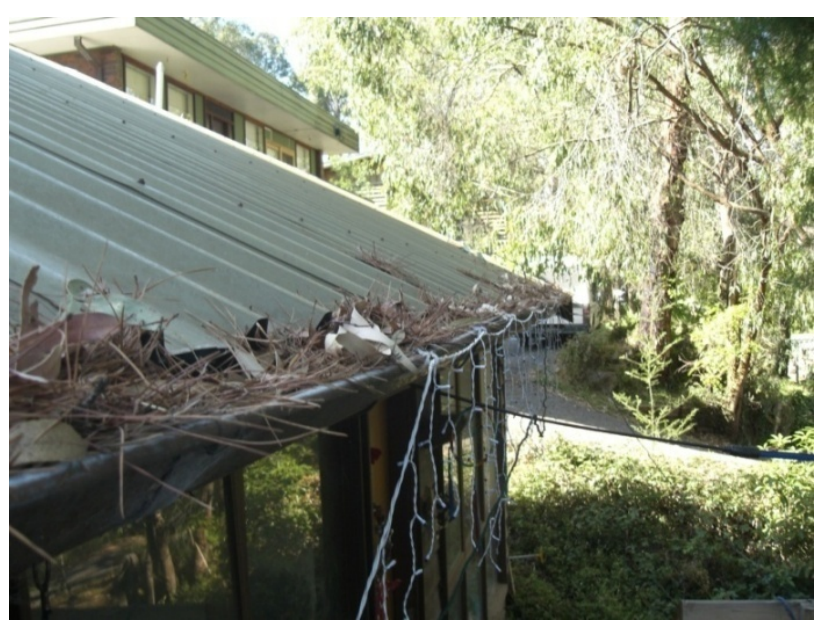

Figure 5. Wooden houses in the tall gums, Outer Melbourne high summer 2007.

\subsection{The Preparedness Sequence}

Although the research indicated a generally high level of awareness and preparedness to act, critically, many fire zone residents would 'decide on the day' whether to leave early or stay and defend. 'Leave early' depends on how far you have to travel to get to a 'safe place'.Defend depends on three factors: firstly, the preparedness and ability of defenders, considering health, psychological preparedness, and physical preparedness including clothing, gear and water supply. Secondly, the defensibility of your home: construction/design - materials, shape, aspect and effective 
seal, proximity of fuel load and a registered fire shelter. Some houses are indefensible in some fires; liable to 'explode' in a firestorm. Finally, the defend decision hinges on the predicted category of the impending fire weather. These considerations are all critical to successful defense.

On $7 / 2 / 9$, crisis departures both saved lives from 'exploding' houses, and caused many deaths (Figures 5 and 6).People are more inclined to respond to a looming threat if they have already achieved the earlier steps of the 7SCS (James et al 2007, Ingirige and Amaratunga 2012).

Figure 7 shows how people who have previously internalised the risk and undertaken the background preparation will be listening up for impact threats, and be inclined to do the final preparations through to early recovery.

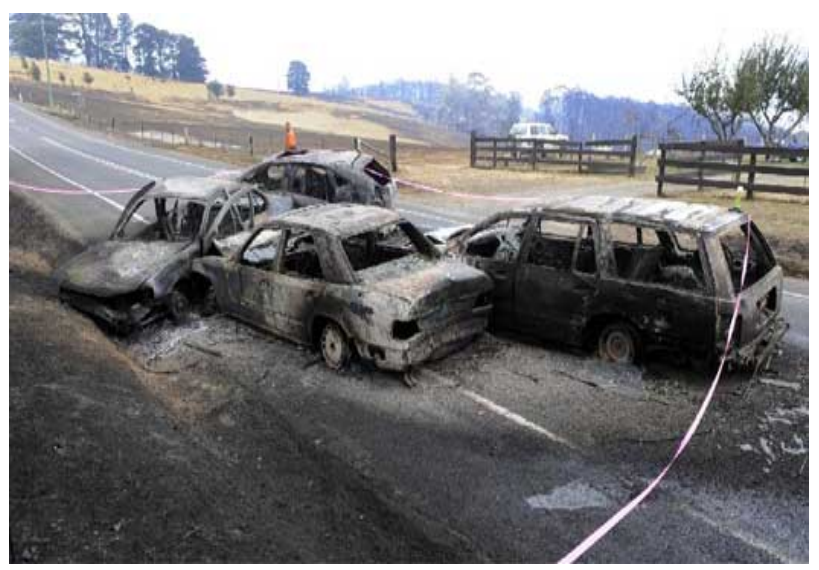

Figure 6. Travelling during a major impact when all options are horrific 7/2/9Reuters, AFP

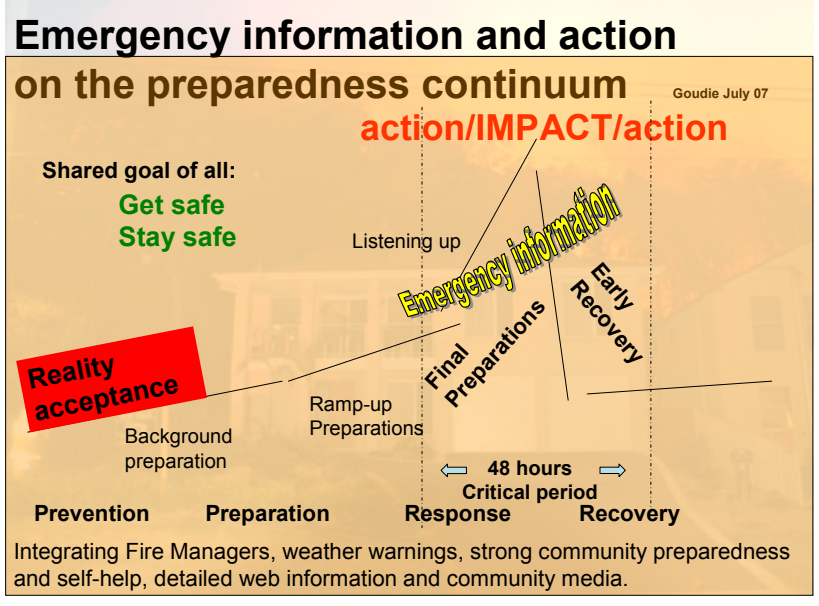

The loose spiked 'graph' is illustrative of emotional levels described by people who have experienced disasters. The lines are not joined because there are disjunctions between the phases illustrated.For instance, the threat may veer away without impact.

Figure 7. The Preparedness Sequence

\section{Simulations}

Simulations of predicted near-term fire or other threat movement, akin to micro scale modelling of cyclone impact forecasts, will help revolutionise the way people react to fire and flood threat (McLean 2007).Simulations of flood height or hail path or fire movement will be challenging to develop, but will help the threatened make sound decisions.

An identified problem in effective risk communication in Australia is the fractured ways different States and territories managed information. Seen from one perspective, it has allowed local innovation, but at the expense of national coherence in the age of smart phones, the internet, up-loads and real-time forecasting and potential two-way information-sharing. This 'fractured' approach may well apply to other countries with 'antiquated' political structures, developed well before our 'information age'. There is a real need to drop issues of 'power protecting' of old political boundaries to work coherently across borders to maximise safety and minimise loss, using all forms of two-way communication and involvement (Steelman and McCaffrey 2012).

\subsection{One National Approach to Disasters, One National Web Site}

Section 51 of the Australian Constitution is now a divisive obstacle to a rational national approach because it gives states responsibility for disaster management (Farnsworth2008). The Council of Australian Governments is trying to develop one national approach to disaster mitigation (COAG 2004). Modern technologies and natural disasters over-ride state boundaries. Perhaps it is time to revisit S51, for safety, health and education.

One national 'Safe Australia' website can link seamlessly to unique state, territory and local information (i.e. MPSC and Robinson 2006). It will greatly reduce the high level of internet information duplication (Goudie 2008b), currently coexisting with many information 'holes'. The national site should include: zoom-in access to all local hazards and real-time, disaster zone mapping and impact simulations. The high level of local government and community safety-oriented innovation revealed by the research suggests there should be a widely known site within 'Safe Australia' to post, share and draw on safety-oriented innovation, with annual regional awards attached to Australia Day acknowledgements of citizen merit.

With easier access to relevant web information, with rapid entry via clicking location on a map of Australia, or by entering a postcode, with greater detail of current disaster behaviour and now-casts, residents-at-risk and local radio announcers can describe the threat, helping timely preparations and the 'stay or go' decision.

\section{Recommendations}

\section{Recommendation 1}

A rational national approach to disaster and climate change mitigation.

Preparedness and emergency communications are the 
peak of much broader levels of preparedness, using the Standard Emergency Warning Signal, one national Safe Australia web-site and Common Alerting Protocols, where crisis communicators use the internet as the main information conduit, collating information and rapidly posted advice for local use. Internet innovation can include: stronger neighbourhood e-links, now-casting local weather conditions and short term predictions. A national, all-hazards approach will include effective mobile phone text messages, email and general use of battery-operated radios to hear and share authoritative information read directly from the web.

\section{Recommendation 2}

Adopt a 5 scale warning system across all threats

Like Cyclone warnings, fire threat can be ranked $1-5$, with five being "Firestorm weather" across relevant bio-regions [this has been adopted for fire in Australia].

\section{Recommendation 3}

Redefine "Leave early or stay and defend".

'Leave early' depends on how far people have to travel to get to a 'safe place'. Defend depends on the preparedness and ability of defenders, the defensibility of a home and the predicted category of the impending fire weather.

\section{Recommendation 4}

The $10 \%$ media pre-impact commitment

Leading into a predicted impact, the media should devote $10 \%$ of likely post-impact coverage in a geographically targeted and timely way to predicted impact zones, using language like fire weather and 'firestorm weather', showing maps and sharing stories. This will help neighbours talk and motivate each other to action, as a precaution, as a practice.

\section{Recommendation 5}

Nurture, share and encourage uptake of local community safety innovations, linked regionally to Australia Day celebrations. Develop a site within the 'Safe Australia' web site to post, share and draw on safety-oriented innovation.

\section{Recommendation 6}

Explore 'over-managed' social burn-offs near vulnerable houses.

This has advantages not only to the householder reducing their fuel load, but provides a social focus to build social capital, especially for newcomers. It also gives those without experience just how hot radiant heat from a managed fire can be.

\section{Conclusion}

Theory, regional perspectives and emerging practice converge on using refined web-delivered material to households and to mobile phones, to their neighbours and to local media, informing and motivating residents through the preparedness sequence in Seven Steps to Community Safety. The processing of agency-gathered information through to residents-at-risk will be enhanced by a Safe Australia website, and the national uptake of Common Alerting Protocols. The fostering and use of community links, community engagement and self-help, while working to provide direct web feed via local radio stations to battery-operated radios to those at risk will greatly reduce the burden on formal response agencies.

By enhancing knowledge-based self-help and more fire-resistant structures prior to fire threat, authorities can best foster final disaster preparations and responses. Assessing personal and property preparedness, fuel loads and near safe-places are all part of emergency warning effectiveness and response decisions to fire threats. Conveying the needed local information, including likely fire threat intensity from a mild but real category 1 through a perhaps manageable Category 3 to a terrifying and easily deadly category 5 - firestorm weather - will help people make decisions in a timely way. Self-evacuation to suburbia for the day can be a very attractive alternative to being in another $7 / 2 / 9$.

The deeper implications of these findings and recommendations are that the very structures of power and control, rather than 'command and control' among fire authorities needs to be constantly revised, in this era and future where psychology and end-user-driven needs-meeting is gaining in ascendency with growing reliance on electronic media, especially mobile phones, battery operated radios and the internet. Two-way communications, targeted and participatory engagement into safety-oriented understandings and behaviour is the direction of effective risk and crisis communication. This will be increasingly aided by on-ground meetings and all forms of media playing expanding roles detailed in this paper, pre-impact through to early recovery, to maximise safety and minimise loss.

People want more fine local detail in time and space and inter-supportive communities (even if virtual).Maximising safety and minimising loss is largely about weather extremes; preparedness and a modern meld of Authorities, technology, the internet and the media interacting with locals. Enhancing these elements is core to engaged, prepared communities. Using the approaches outlined in this paper, people will generally have minimised disaster vulnerability and be better placed for smooth recovery, minimising disruption and recovery costs.

\section{Acknowledgements}

Thanks for the ongoing support of A. Professor David King, Director, Australian Centre for Disaster Studies, JCU and from the Australian Bureau of Meteorology. The fire-warnings research was funded by the Australian Bushfire Cooperative Research Centre. Thanks to the many on-ground fire fighters and managers for their help, and some central fire Agencies for their keen interest and support. My greatest appreciation extends to the many meeting attendees, especially in Canberra post 2003, the 22 at Phantom Hill, people on the Mornington Peninsula and all Fire managers for their on-ground experiences and feedback. Thanks to all interviewed hazard-prone householders, who 
motivated and informed this research.

\section{REFERENCES}

[1] Botterell A et al (2008).A Roadmap to Emergency Data Standardshttp://www.incident.com/cookbook/index.php/A Roadmap_to_Emergency_Data_Standards

[2] Boura J (1998).Community Fireguard: Creating partnerships with the community to minimise the impact of bushfire. Australian Journal of Emergency Management, 13, 59-64.

[3] COAG (2004).Natural Disasters in Australia, reforming mitigation, relief and recovery

arrangements.http://www.ema.gov.au/agd/EMA/rwpattach.n sf/VAP/(756EDFD270AD704EF00C15CF396D6111) COA $\mathrm{G}+$ Report + on+Natural+Disasters + in + Australia +-+ August +2 002.pdf/\$file/COAG+Report+on+Natural+Disasters + in + Aus tralia+-+August+2002.pdf Council of Australian Governments Commonwealth of Australia.201.

[4] Cohen E, White P and Hughes P (2006).Bushfire and the Media Reports $1-3$.Latrobe University and BCRC.

[5] Country Fire Authority (2003).History of the CFA. http://www.cfa.vic.gov.au/teachers/documents/fact-sheets/fa ctsheet-history.pdf

[6] Country Fire Authority (2008). Community Fire Guard.(CFA 2008)

(http://www.cfa.vic.gov.au/residents/programs/cfg.htm

[7] Farnsworth M (2008).Federalism http://australianpolitics.com/constitution/federalism/

[8] Goudie D and King D (1999).Cyclone surge and community preparedness.Austn. J. of Emergency management. 13:1, 454-60.http://www.ema.gov.au/agd/EMA/rwpattach.nsf/vie wasattachmentpersonal/(85FE07930A2BB4482E194CD036 $85 \mathrm{~A} 8 \mathrm{~EB}) \sim$ Cyclone surge and community preparedness.pd f/\$file/Cyclone_surge_and_community_preparedness.pdf

[9] Goudie D (2004).Disruptive weather warnings and weather knowledge in remote Australian Indigenous communities. Web-based

reporthttp://www.tesag.jcu.edu.au/CDS/reports/Gou IWWR $\mathrm{pt} /$ index.shtml

[10] Goudie DD (2007). Poster: Project C4b: Effective risk communications - warnings. Community preparedness, emergency information transfer and uptake. Australasian Fire Authorities/Council and Bushfire CRC Annual conference,Hobart.http://www.bushfirecrc.com/managed/res ource/c-goudie.pdfhttp://www.jcu.edu.au/cds/public/groups/ everyone/documents/conference poster/jcutst_056268.pdf

[11] Goudie DD (2008a). Improving Delivery of Safety-oriented Weather Information for Non-English Speaking Households. Bushfires as an example. James Cook University. Centre for Disaster Studies

139.http://www.tesag.jcu.edu.au/CDS/Pages/reports/08\%20 W\%20NESH\%20Fin\%201\%20a.doc

[12] Goudie DD (2008b).Bushfire Web Review 2006/7 James Cook University. Centre for Disaster Studies.65.

[13] Goudie DD (2009a).Internalizing Survival Values into
Science: Sustainability Implementation Science. The International Journal of Science in Society. 1:3;x1- 22. CGPublisher.http://ijy.cgpublisher.com/product/pub.187/pro d.50http://eprints.jcu.edu.au/10334/

[14] Goudie DD (2009b).Final report Effective remote Indigenous risk communication via radio 2009.http://eprints.jcu.edu.au/5 $460 /$

[15] Goudie D (2013). Natural Disasters and evacuations as a Communication and Social Phenomenon. In: Meyers R. (Ed.) Encyclopedia of Complexity and Systems Science: Springer Reference (www.springerreference.com) Springer-Verlag Berlin Heidelberg, 2013.

Doi: 10. 1007/SpringerReference_60358 2013-06-18:18:31 UTChttp://www.springerreference.com/docs/html/chapterdbi d/60358.html

[16] Handmer J (2001).Improving flood warnings in Europe: a research and policy agenda. Environmental hazards. 3:2001.19-28. Pergamon. http://www.massey.ac.nz/ trauma/ issues/2000-2/handmer.htm. ISR (2007).Australian Policyonline.Institute for Social Research, Swinburne University of Technology. http://www.apo.org.au/linkboard/ results.chtml?filename num $=117732$

[17] Handmer J (1992).Can we have too much warning time? A study of Rockhampton, Australia. The Macedon Digest. The Australian Journal of Disaster Management 7:2 p 8-10.

[18] Handmer J (2001).Improving flood warnings in Europe: a research and policy agenda. Environmental hazards. 3:2001.19-28. Pergamon.

[19] Handmer J (2000).Are Flood Warnings Futile? Risk Communication in emergencies.2000:2,

Pages (e) 1 - 14.http://www.massey.ac.nz/ trauma/issues/2 000-2/handmer.htm

[20] Ingirige B and Amaratunga D (2012). Minimising flood risk accumulation through effective private and public sector engagement. Geneva,Switzerland:UNISDR.http://www.prev entionweb.net/english/hyogo/gar/2013/en/bgdocs/Ingirige $\% 2$ 0and\%20Amaratunga,\%202012.pdf

[21] James X Hawkins A and Rowel R (2007).An Assessment of the Cultural Appropriateness of Emergency Preparedness Communication for Low Income Minorities, Journal of Homeland Security and Emergency Management:4:3, Article 13, p 1 -24.http://www.bepress.com/jhsem/vol4/iss3/13

[22] Kim YC and Ball-Rokeach SJ (2006).Civic engagement from a communication infrastructure perspective. Communication Theory. 16:2006, 173-197.

[23] King D and Goudie D (1998). Breaking through the disbelief the March 1997 floods at Cloncurry.Even the duck swam away.Aust. J. Emergency Management. 4:1229-33.

[24] King D and Goudie D (2006). Cyclone Larry, March 2006 Post Disaster Residents Survey. Centre for Disaster Studies, James Cook University, with the Australian Bureau of Meteorology.P77.http://www.jcu.edu.au/cds/public/groups/e veryone/documents/technical_report/jcutst 056193.pdf

[25] King D, Goudie D and Dominey-Howes D (2006).Cyclone knowledge and household preparation - some insights from Cyclone Larry Report on how well Innisfail prepared for Cyclone Larry. The Australian Journal of Emergency Management, 21:3 52-59 
August 2006. http://www.ema.gov.au/agd/EMA/rwpattach.n sf/VAP/(A80860EC13A61F5BA8C1121176F6CC3C) AJE M EMA_Larry_Aug2006.pdf/\$file/AJEM_EMA_Larry_Au g2006.pdf

[26] McLean C (2007).Distributed Simulation - A Necessity or Ivory Tower Research? Panel Position Statement, Proceedings of the 2007 Winter Simulation Conference, Washington, DC.

[27] MPSC and Robinson G (2006).Fire wise fire management. h ttp://www.mornpen.vic.gov.au/Files/FireWiseFireManageme ntBooklet.pdf Mornington Peninsula Shire Council. 31.

[28] O’Neill P (2004). Why don't they listen - Developing a risk communication model to promote community safety behaviour.The International Emergency Management Society, 11th Annual Conference Proceedings, May 18-21, 2004, Melbourne, Victoria, Australia 160-169, 2004.

[29] Paton D, Smith L and Johnston D (2005). When good intentions turn bad: promoting natural Hazard preparedness. The Australian Journal of Emergency Management 20: 25 30.

[30] Paton D (2003) Stress in Disaster Response: A risk management approach. Disaster Prevention and Management, 12:3, 203-209.

[31] Paton D, Smith L and Johnston D (2005). When good intentions turn bad: promoting natural Hazard preparedness. The Australian Journal of Emergency Management 20: 25 30 .

[32] Quarantelli EL (2002). The role of the Mass Communication system in natural and technological disasters and possible extrapolation to terrorism situations. Risk Management: An International Journal.4: 4, $7-21$.

[33] Rohrmann B (2000a).A socio-psychological model for analysing risk communication processes. The Australasian Journal of Disaster and Trauma Studies Volume: 2000-2.http://www.massey.ac.nz/ trauma/issues/2000-2/rohr mann.htm

[34] Rohrmann B (2000b).Critical assessment of information on bushfire preparedness for residents. The Australian Journal of Emergency Management, 15:1. 14 - 19.
[35] Sorensen R (2013).Lessons Learned from Cyclones in Northern Australia. Australian Government. Rural Industries Research and Development Corporation Pub. No. 13/071, Project No. PRJ-008498. 91. https://rirdc.infoservices.com.au/items/13-071

[36] Strahan Research (2008). Community attitudes to bushfire safety prior to $2007 / 08$ summer season. Commissioned by the Country Fire Authority.http://www.cfa.vic.gov.au/document s/CommunityAttitudesBushfireSafety.pdf25

[37] Steelman TA and McCaffrey S (2012).Best practices in risk and crisis communication: Implications for natural hazards management

Nat Hazards (2013) 65:683-705 DOI 10.1007/s11069-012-0 386-zhttp://br9xy4lf5w.search.serialssolutions.com.elibrary.j cu.edu.au/?\&url ver=Z39.88-2004\&url_ctx fmt=info:ofi/fm t:kev:mtx:ctx\&rft_val_fmt=info:ofi/fmt:kev:mtx:journal\&rft .atitle=Best $\% 20$ practices $\% 20$ in $\% 20$ risk $\% 20$ and $\% 20$ crisis $\% 2$ 0communication $\% 3 \mathrm{~A} \% 20$ Implications $\% 20$ for $\% 20$ natural $\%$ 20hazards\%20management\&rft.aufirst=Toddi $\% 20 \mathrm{~A} \% 2 \mathrm{E} \& \mathrm{rf}$ t.aulast $=$ Steelman $\&$ rft.date $=2013 \&$ rft.epage $=705 \&$ rft.genre $=$ article\&rft.issn $=0921-030 \mathrm{X} \& \mathrm{rft}$.issue $=1 \& \mathrm{rft}$.jtitle $=$ NATUR AL\%20HAZARDS\&rft.pages $=683-705 \&$ rft.spage $=683 \&$ rft. stitle $=$ NAT $\% 20$ HAZARDS\&rft.volume $=65 \&$ rfr $i d=$ info:sid /www.isinet.com:WoK:UA\&rft.au $=$ McCaffrey $\% 2 \mathrm{C} \% 20$ Sara h\&rft id=info:doi/10\%2E1007\%2Fs11069-012-0386-Z

[38] UNISDR (2012).Essential Nine: Effective Preparedness, Early Warning and Response. United Nations Office for Disaster Risk Reduction. http://www.unisdr.org/campaign/re silientcities/toolkit/essentials/view/9

[39] Wakefield SE and Elliot SJ (2003).Constructing the news: the role of local newspapers in environmental risk communication. The Professional Geographer. 55:2 216-266.

[40] Wall M (2006).The case study method and management learning: making the most of a strong story telling tradition in emergency services management education. The Australian Journal of Emergency Management, 21:2, 11- 16.

[41] Yang ZJ and Kahlor LA (2013). What, Me Worry? The Role of Affect in Information Seeking and Avoidance. Science Communication.35(2) 189-212.SAGE Publications. DOI:10.1177/1075547012441873.scx.sagepub.comhttp://scx .sagepub.com.elibrary.jcu.edu.au/content/35/2/189 